\title{
Sexual behaviour of lowland anoa (bubalus depressicornis) in the captivity of anoa breeding centre (ABC) Manado*
}

\author{
Anita Mayasari ${ }^{1}$, Diah Irawati Dwi Arini $^{2}$, Ady Suryawan $^{2}$, Rahma Suryaningsih ${ }^{2}$, Renaldi Ednin Vernia $^{1}$, Abinawanto \\ Abinawanto $^{1}$, Ade Suryanda ${ }^{3}$, and Anom Bowolaksono, ${ }^{1, *}$ \\ ${ }^{1}$ Department of Biology, Faculty of Mathematics and Natural Sciences, University of Indonesia, 16424 Depok, West Java, Indonesia \\ ${ }^{2}$ Environment and Forestry Research and Development Institute of Manado, Adipura road, Kima Atas, Mapanget, 95259 Manado, North \\ Sulawesi. Indonesia \\ ${ }^{3}$ Department of Biology, Faculty of Mathematics and Natural Sciences, National University of Jakarta, Rawamangun Muka road No. 1, \\ 13220 East Jakarta, Indonesia
}

\begin{abstract}
Low land Anoa is an endangered and endemic species to Sulawesi. The solitary, monogamous, wild and aggresive characteristic make them difficult to mate. The purpose of this study was to determine the sexual behaviour of young anoa pairs and mature anoa pairs at ABC. The study was conducted on 4 until 16 August 2017. Behavioural observation was done using animal focal sampling technique by recording the sexual behaviour that occur during the mating process of each pair. The results showed there are differences in sexual behaviour between the pairs of anoa. In the young anoa pairs, there were no attempted of mounting behaviour, penile erection, penile intromission.
\end{abstract}

\section{Introduction}

Low land anoa or Bubalus depressicornis belongs to the smallest endemic Bovine Genus at Sulawesi and Buton Island [1-4]. The $B$. depresicornis relatively has a larger size, darker color, thinner fur $[5,6]$ taler and bigger than B. quarlesi. [7] Anoa is categorized as endangered species $[4,8]$.

The population of anoa currently remains 2.500 with a growth rate of $14-18 \%$ per year [3]. The anoa population in Tangkoko Nature Reserve had been declared extinct locally [9]. Anoa population continue to decline due to hunting and habitats loss $[1,10]$. Both ex situ and in situ conservation provides opportunities for nature breeding $[1,6]$. Ex situ conservation is importance to conserve anoa $[11,12]$, because nowadays anoa is seen in agricultural areas adjacent to forest [13].

Research on anoa at the captivity in Indonesia has been widely practiced, which are related to breeding $[12,14]$, Anoa's diet $[6,15,16]$, reproductive organ bio metric and ejaculate characterization [17], bio metric and spermatozoa [18], cryopreservation of cement and its characteristics [19], reproductive behaviour, cement preservation and artificial insemination techniques of Anoa in the zoo [20], and estrous observation [21]. The 1 of 4 artificial inseminated anoa was successfully gave birth [22]. Breeding management of anoa should be comprehensively understood in an effort to conserve exitu. Anoa is difficult to breed due to its solitary nature, wild, monogamous, and tend to fight when they meet $[17,13]$.

Information related to the natural mating behaviour of anoa is very important to learnt for the successful breeding. Behaviour shown by anoa in breeding enclosure is not significantly different with the behaviour in nature [15]. In the Bovine family, the mating process will generally be preceded by fights between males and females, so is the anoa $[22,23]$. Fighting is a form in natural selection process based on the male performance $[24,25]$. Buffalo have 3 stages when mated there are pre-copulatory, copulatory, and post-copulatory [26]. This is justified that learning the sexual behaviour of anoa is important to succeed breeding.

The age factor affects reproduction performance of cattle. It was positively correlated with the sperm volume in Simental cow [27] and the size of the scrotum in PE goat [28]. Male sexual behavior affects the release of LH hormone and anovultaion period in female sheep [29]. The reproductive quality of buffalo is affected by age, weight and size of testes [30]. The reproductive character and immunity of buffalo is higher in males and older than females and younger [31]. In female buffaloes, the age factor is positively correlated with the success of birth [32]. The older the females the higher the birth rate. Differences in reproductive performance in young and mature buffalo occur in behavioral parameters, whereas the signs of estrus do not differ

\footnotetext{
* Supported by the International Publication for Final Project Grant (Hibah PITTA) No. 620/UN2.R3.1/HKP.05.00/2017, Universitas Indonesia. A. M. is supported by the Indonesia Endowment Fund for Education (LPDP Scholarship) from the Ministry of Finance, Indonesia

*** Corresponding author: alaksonor@sci.ui.ac.id
} 
[33]. The study aims to obtain information on sexual behaviour of male and female anoa in ABC.

\section{Materials and Method}

\subsection{Study area}

The research was conducted at Anoa Breeding Centre Manado which is located in The Environment and Forestry Research and Development Institute of Manado, Ministry of Environment and Forestry (Fig. 1). The study was conducted on 4 to 15 August 2017 from 7:00 to 16:30 ICST. Sexual behavioural observations were performed during the estrous periode. The estrous periode is determined based on by behavioural observation and changes in epithelial cell features since July 17, 2017.

\subsection{Material and Procedure}

\subsubsection{Material}

The anoas were placed in breeding enclosue. There were two pairs of anoa (Fig. 1), the mature one is Rambo (6 y.o) and Manis (8 y.o) and the young pair is Rita and Roki (both are 3.5 y.o). Both of female have never pregnant before. The four anoa were ready to be naturally mated. The equipment used includes michroschope, steril cotton swab (2,2 mm x $150 \mathrm{~mm})$, DSLR camera, logbook, clock, bunsen burner, meter line, NaCL 0,9\%, and Giemsa stain.

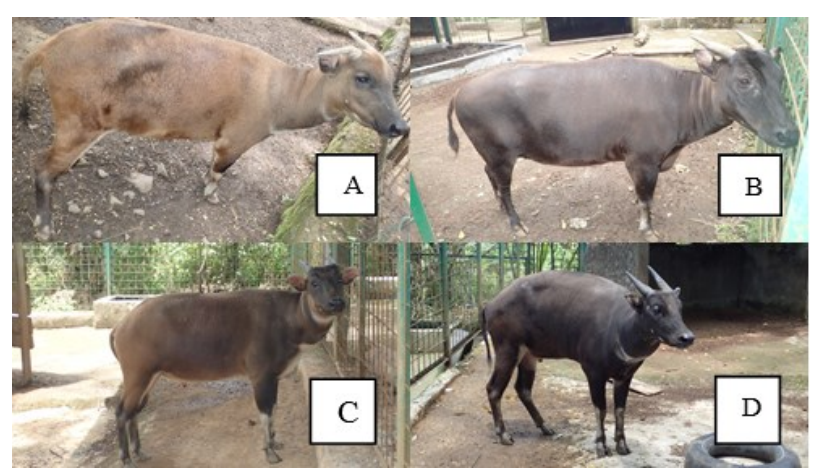

Remark : female A (Rita) and B (Manis); male C (Roki) and D (Rambo)

Fig. 1. The pairs of mature (B and D) and young (A and C).

\subsubsection{Procedure}

The four anoa morphometric data were taken using technique Siamtiningrum [34] that has been modified (Fig. 2) dibawah ini.

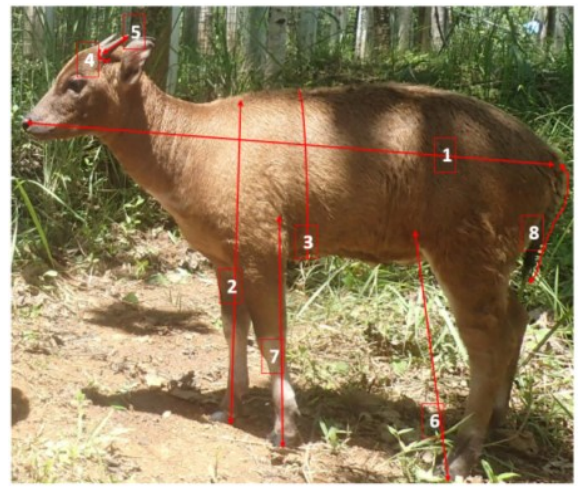

(Description: 1. Body length, 2. Height, 3. Bust, 4. Base horn circumference, 5. Horn length, 6. Hindleg heght 7. Foreleg height, 8. Tail length).

Fig. 2. Morphometric measurement parameter.

Behavioural estrous were compared to the vaginal cytology observations. Cotton swab were used for cell collection. Cotton swab were moistened with $\mathrm{NaCL}$ $0,9 \%$ and introduced into the vagina approximately 1,5 $\mathrm{cm}$, quickly and gently rotated against the floor of the vagina. The epithelial cells obtained were immediately prepared by rotating the cotton swab along a glass side. The smear was fixed using bunsen burner. Then stained with Giemsa and leave it for 10-20 minutes. Then washed it in the tap water, leave it air dried for a moment and fixed again using bunsen burner. The stained slides were examined using michroschope with magnification of 40X [20].

The observed mating behaviours include grinning in males (flehmen), rubbing horns or heads into female bodies, approaching females, sniffing/genital licking, mounting, raising and wagging of the tail, urination, erection, and intromission. Sniffing includes kissing and licking the vulva. Mounting is when the male step into the female although there is no intromission/inclusion of the penis into the vagina, whereas urination is when the male or female urinate.

\section{Results and Discussion}

\subsection{Result}

Table 1. The morphometric af anoa.

\begin{tabular}{|l|c|c|c|c|}
\hline $\begin{array}{l}\text { Name / } \\
\text { Parameter }\end{array}$ & $\begin{array}{c}\text { Rambo } \\
(6 \text { y.o })\end{array}$ & $\begin{array}{c}\text { Rocky }{ }^{\wedge} \\
(3,5 \text { y.0 })\end{array}$ & $\begin{array}{c}\text { Manis }+ \\
(8 \text { y.o })\end{array}$ & $\begin{array}{c}\text { Rita }+ \\
(3,5 \text { y.o })\end{array}$ \\
\hline Bl & 150 & 140 & 152 & 138 \\
\hline H & 98 & 88 & 88 & 82 \\
\hline B & 56 & 54 & 59 & 54 \\
\hline Bhc & 16 & 15 & 11 & 11 \\
\hline Hl & 22 & 23 & 21 & 15 \\
\hline Hh & 67 & 50 & 58 & 50 \\
\hline Fh & 47 & 43 & 46 & 47 \\
\hline Tl & 38 & 26 & 30 & 22 \\
\hline Colour & Dark & Brown & Dark & Brown \\
\hline
\end{tabular}

(BL: body length, H: height, B: bust, Bhc: base horn circumference, $\mathrm{Hl}$ : horn length, Hh: hindleg height, Fh: foreleg height, Tl: tail length) 
Based on morphological measurement, all of the anoa are having a different size of body. The older male and female anoa are having bigger body than the younger one. The younger anoa are having brighter fur color than the older (Fig. 1). Each anoa are having a similar characteristic with the mate.

Observation of mating behaviour was started since the male and female are paired. Here are the observations presented in Fig. 3 merupakan gambara perilaku yang dilakukan mulai fase pre, copulation dan post copulatian. Fig. 4 perbandingan intensitas perilaku yang muncul antara kedua pasangan dan Fig 5 . Perbandingan perilaku kedua pasangan berdasarkan waktu harian.

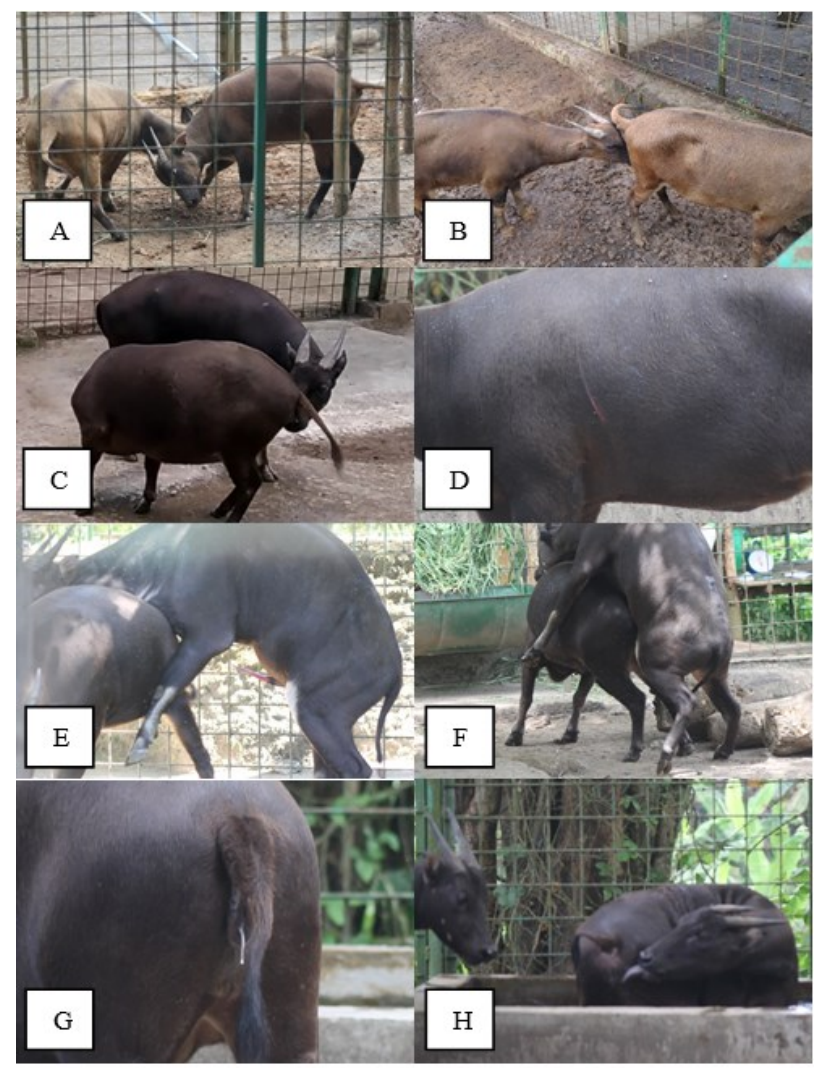

(A: mutual gore, B: sniffing, C.:mutual sniffing, D: wound marks, E: mounting (rising females without intromission), F: mounting, G: mucus in the vulva (males liquid cement), $\mathrm{H}$ : wallowing).

Fig. 3. Natural mating process in adult and young anoa couples.

At the beginning of the mating process, the couple will run into a fight between each other (Fig. 3 A). It can cause a light or even heavy wound to them. Fig. 3 D show how the female body wounded by the male. When the male win, the female will be obedient to the male. This kind of behavior can be found both in the young or old anoa.

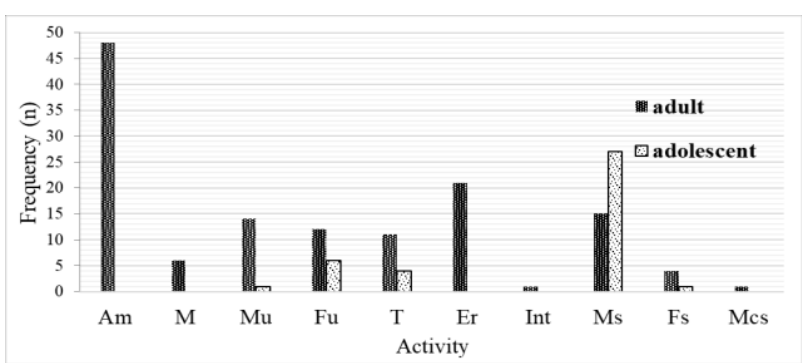

(AM: attempting mounting, $\mathrm{M}$ : mounting, MU: male urination, FU: female urination, Tail: raising and wagging tail, E: erection, Int: intromission, MS: male sniffing/licking, FS: female sniffing/licking, Mcs: mucus erosion)

Fig. 4. The sexual behaviour differences in adult and young anoa pairs.

Based on the graph, the intensity of the behavior on Fig. 4 is the behavior that occur a lot. There are sniffing and licking the genital part (perineal). This behavior is mostly done by male anoa. The male will move its nose closer to the buttocks of the female, sometimes rubbing it, sniffing and lick the female genital area as shown on Fig $3 \mathrm{~B}$. The females are usually dodging, but sometimes it is just staying still and let the male sniff out in her genitals for a while. In contrast to the adult anoa pair, the activity of sniffing or licking of the genital area is mostly done by female anoa (seen in Fig $3 \mathrm{C}$ female head lower) in the younger pair. In adult anoa the sexual behavior that emerges is dominated by the activity of attempting mounting (Fig 3 E) and mounting (Fig 3 F). This behavior is done by male anoa. Based on observations, younger females are likely will escape or dodge the males. When the female leaves, the male will follow her. In the post copulation phase, female anoa will enter the mud (Fig $3 \mathrm{H}$ ) and sperm can be spotted out of the female vulva (Fig $3 \mathrm{G}$ )

Table 2. Mann-whitney test, the sexual behaviour differences of both anoa pairs.

\begin{tabular}{|l|l|}
\hline Parameter & Z count \\
\hline Behaviour & -2.525 \\
\hline Sig. & $0.011^{\mathrm{a}}$ \\
\hline
\end{tabular}

Based on the table 2, sig. value from Mann Whitney Test $<0,05$ which mean that there is a differences in sexual begaviours between young and old anoa.

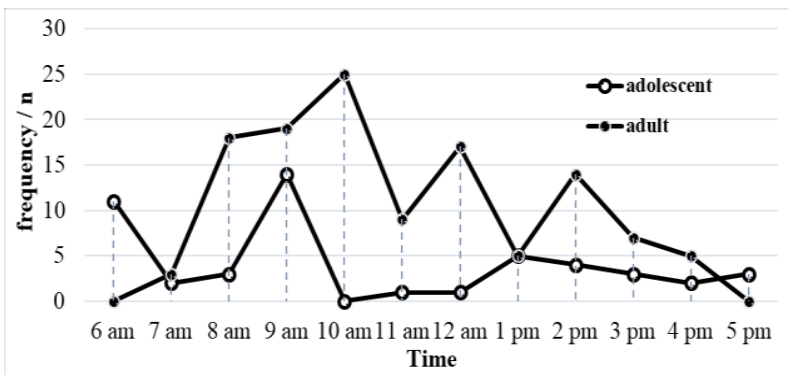

Fig. 5. Frequency of mating behaviour based on time of occurrence. 
Based on the daily behavior that appears in Fig 5, adult anoa mating behavior is more often occur at 9 o'clock. While the young anoa occurs at 10 o'clock. The frequency of mating in adult anoa is higher than young anoa. On the feeding time, the adult male anoa will dominate the foodd. The adult females will wait while aproachin the food sometimes when there is a chance. In contrast, the young anoa couples are more likely sharing the food. In the afternoons, the two anoa pairs tend not to show mating behavior, but based on observations, at around 17.30 an adult male anoa is seen mounting.

\subsection{Discussion}

Anoa mating behavior can be divided into 3 phase, there are pre-copulatory, copulatory, and post-copulatory [25]. Pre-copulatory is marked by the courtship activity. Copulatory is marked by sexual acceptance of males. Post copulatory is a temporary rest period after copulatory, usually males do not show sexual activity.

Fighting behavior with is usually occurring when the male is meeting the female for the first time, either in adult or young adolescents (Fig $3 \mathrm{~A}$ ). The behavior actually occurs naturally to initiate the natural mating of anoa, but not infrequently causes an injury that results in death [19]. Therefore, the anoa mating process should be under supervision. If the battle is perceived to be dangerous, then both male and female anoa should be separated immediately. In addition to minimizing the risk of injury from the fight, anoa will only be paired at the estrus peroid. The estrus cycle is a psychological and physiological period in which the female is willing to accept and respond to the male [26]. At the time of estrus, the female anoa is likely to accept the presence of the male anoa. Based on the cytology observations of the vaginal reviews, the adult female is experiencing estrus on August 5, 2017 and young female on August 13, 2017. The estranging female anoa shows restless behavior, frequent urination, mucus out of the vagina, changes in the vulva (red, swollen, wet) often lifting and wagging the tail $[19,35]$.

When paired, the two pairs of adult anoa (Rambo and Manis) and young anoa (Rocky and Rita) show estrus traits. The behavior of urination can be used as an easy observable parameter of estrus. When the anoa is mating, adult males perform urination up to 14 times/day and females 12 times/day. In young anoa pairs, only females show urination up to 6 times/day (Fig 4 in the Fu and $\mathrm{Mu}$ columns). Female anoa will secrete urine more often, especially every time she encounter males, it is will increasing twice time at the time of estrus [19]. Increased frequency of urination when estrus also occurs in mud buffalo with recorded averaged 19 times/day [25].

The male anoa will follow the female anoa, sniff and lick the genital parts (Fig.3 A, B, C). the male will still Sniff the genitals even when the female is urinating, eating, and still. When the female is urinating, males will sniff and lick the female urine and perform flehmen. Uphold the neck, open mouth, upper lip folded to cover the nose, and show the teeth (Figure ....). Flehmen are distinct courtship components [25] that appear after males sniff the urine or female's genital [36]. Adult female is usually silent when the males come up and do the courtship activities (Fig 3. C). While young female anoa is more often avoid it when the males approaching (Fig $3 \mathrm{~B}$ ). The pre-copulatory behavior is shown in Figure $3(a, b, c)$.

Mounting and mounting attempt are the dominant sexual behavior in adult anoa pairs (Figures $3 \mathrm{E}$ and F). The behavior begins with sniffing or kissing the female genitals. Mounting is done by putting the chin on the back of the female, the female responds by giving pressure using her back. Then the males will put the front legs on the female hips, hold them, and push the pelvis forward. Followed by the penetration of the penis into the vulva-vagina. The male will ejaculate the sperm and then dismounting. The mounting attempt performed by males are usually not directly successful. The mounting attempt on the anoa occurs several times before it is actually mounted [11,19]. The mounting process that is not followed by penetration is often caused by wrong estimation estrus lifetime [25]. Female animals are still in pro-estrus period and so they are not willing to accept the male presence sexually.

Post-copulatory behavior in adult anoa can be seen in Figure $3 \mathrm{G}$ and $\mathrm{H}$, female Anoa is seen to be licking mucus sticking in its genital part. The mucus is a cement fluid released by a male anoa. The females are also seen entering the pool of water, soaking, and re-licking the genital part. After several mounting times, the male anoa appears not to engage in any sexual activity. The males are just following the female anoa into the pool of water then rest. There are differences in sexual behavior in young and adult anoa pairs. Although both are paired at the time of estrus, but the behavior shown by young and adult anoa turns out to be different. More copulatory behavior is performed by adult anoa pairs. while younger anoa more often run away from male anoa. Age factors have a significant effect on animal reproduction performance [28-33]. The older the buffalo, the higher the reproductive character and immunity [27], and the greater the chances of successful birth [28].

\section{Conclusion}

Based on the results of the observation, there are differences in sexual behavior between adult and young adult couple. In adult anoa couples, pre-copulatory behavior is the dominant behavior, whereas in adult anoa couples copulatory behavior becomes the most dominant behavior.

I thank to Ir. Dodi Garnadi, M. for the support and permission to conduct research on ABC Manado. I also grateful to Adven Joy Simamora who provide data of anoa and guide me along the data collection. I also wish to thank Margaret Christita who offered sugestion to improved the manuscript. I also thank to Edy Suprapto as keeper of $\mathrm{ABC}$ for his kind help. 


\section{References}

1. J.A. Burton, A.H. Mustari, A. McDonald, M. Kons. 12, 2 (2007)

2. L.A.F. Frantz, A. Rudzinski, A.M.S. Nugraha, A. Evin, J. Burton, A. Hulme, A. Linderholm, R. Barnett., R. Vegta, E.K.I. Pease, J. Haile, R. Allen, K. Leus, J. Shepard, M. Hillyer, S. Gillemot, J. Hurk, S. Ogle, C. Atofanei, M.G. Thomas, A.H Mustari, Biorxiv (Preprint), 1, 22 (2018)

3. D.I.D. Arini, N.I. Wahyuni, J.P.K. Wallace, 5, 1 (2016)

4. T. Fukuda, Y. Lino, T. Eitsuka, M. Onuma, M. Katayama, K. Murata, M.I. Murayama, K. Hara, E. Isogai, T. Kiyonon, Cytotechnology, 68 (2016)

5. C. Groves, Beaufortia, 12 (1969)

6. A.H. Mustari, A.U. Prilianti, B. Masyud, M. Kons. 20, 3 (2015)

7. R. Rozzi, Qua. Sci. Rev. 157 (2017)

8. S. Tandilolo, R. Wulandari, Rukmi, W. Rimba 1, 1 (2013)

9. J.S.I.T. Onibala, S. Laatung, Proceeding of the mini workshop Southeast Asia Germany Alumni Network (SEAG). Supplement 90 (2007)

10. R.A. Ranuntu, S.N. Malombasang, J.M.Sains, 3, 2 (2015)

11. K. Kasim, Potensi Anoa (Bubalus depressicornis dan Bubalus quarlesi) sebagai Alternatif Satwa Budidaya dalam Mengatasi Kepunahannya [Desertasi]. Bogor: Institut Pertanian Bogor (2002)

12. M. Basri, Suryahadi, T. Toharmat, H.S. Alikodra, M. Pet. 31, 1 (2008)

13. G.Z.L. Froese, A.L. Castati, A.H. Mustari, J.F. Brodie, J.Trop.Eco. 31 (2015)

14. R.I. Pujaningsih, C.I. Sutrisno, Y.S. Ondho, A. Malik, Anim. Pro. 1, 3 (2010)

15. D.I.D. Arini, Y. Kafiar, J. Was. 1, 2 (2014)

16. Yudi, T.L. Yusuf, B. Purwantara, D. Sajuthi, S. Mulyono, J. Manansang, M. Pet. 32, 1 (2009)

17. Yudi, T.L. Yusuf, B. Purwantara, M. Agila, T. Wresdiyatib, D. Sajuthic, Adityaa, J. Manangsang, R. Sudarwati, Y.T. Hastuti, M. Pet. 33, 2 (2010)

18. Yudi, TL Yusuf, B Purwantara, D Sajuthi, M Agil, J.I.T.V. 16, 1 (2011)

19. Judi, Kajian Perilaku Reproduksi, Preservasi Semen, dan Teknik Inseminasi Buatan Pada Anoa (Bubalus sp.) di Penangkaran [Desertasi]. Bogor [Indonesia]: Institut Pertanian Bogor (2012)

20. M.R.M. Lago, E. Pudjihastuti, R.H. Wungow, L.R. Ngangi, J. Kinho, J. Zoo. 36, 2 (2016)

21. Judi, T.L. Yusuf, B. Purwantara, D. Sajuthi, M. Agil, J. Manangsang, R. Sudarwati, Y.T. Hastuti, B. Huaso, A. Widianti, S. Prastiti, M. Pet. 35, 2 (2012)

22. P.J. Buzard, D. Xu, H. Li, J. Chi. Sci. Bul. 59 (2014)

23. T.C. Brock, K. McAuliffe, J. 84, 1 (2009)
24. J. Byers, E. Hebbets, J. Podos, Ani. Beh. 79, 4 (2010)

25. N. Hasibuan, Tanda-tanda estrous dan tingkah laku kawin kerbau Murrah (Bubalus bubalis) [Skripsi]. Medan: Fakultas Pertanian Universitas Sumatera Utara (2013)

26. Najamudin, Rusdin, Sriyanto, Amrozi, S. Agungpriyono, T.L. Yusuf, J. Vet. 11, 2 (2010)

27. A. Nyuwita, T. Susilawati, N. Isnaini, J.Ter.Tro. 16, 1 (2015)

28. M. Hendri, G. Riady, R. Daud, J.I.M.Vet. 2, 1 (2017)

29. J.C.M. Alfaro, H. Hernandez, J.A. Flores, G. Duarte, G.Fitz-rodrigues, I.G. Fernandes, M. Bedos, P. Chemineau, M. Keller, J.A. Delgadillo, J. Vielma, J. Theriogenology 82 (2014)

30. P.A.C. Luz, P.R.S. Santos, C. Andrigheto, A.M. Jorge, A.C Assis-Neto, J. Repro and Dev 59, 1 (2013)

31. Z.A. Pampoori, S. Pandiyta, J. App. Ani. Res. 43, 1 (2015)

32. S. Rasyid, E.M. Sari, Mahyuddin, J.I.M. Per. Unsyiah 2, 1 (2017)

33. Niati, S. Analisis Komparatif Penampilan Berahi Ternak Kerbau Dara dan Induk Di Desa Sungai Pinang, Kecamatan Tambang Kabupaten Kampar Provinsi Riau [Skripsi]. UIN Sultan Syarif Kasim Riau Pekanbaru, Peternakan. Riau: UIN Sultan Syarif Kasim Riau Pekanbaru (2011)

34. G. Siamtiningrum, B.W. Putra, R. Priyanto, J. Ilmu Produksi dan Teknologi Hasil Peternakan 4, 1 (2016)

35. B. Purwantara, Filogeni, ekologi, variasi genetika dan reproduksi Anoa (Familia Bovidae) di Wilayah Sulawesi Tenggara, Laporan Riset Unggulan Terpadu IX. Bogor. LPPM IPB (2003)

36. M.R. Toelihere, Ilmu Kebidanan Pada Ternak Sapi dan Kerbau. UI Press (2010) 